OPEN ACCESS

Edited by: Miroslav Nikolic,

University of Belgrade, Serbia

Reviewed by:

Yongchao Liang,

Zhejiang University, China

Rivka Elbaum,

Hebrew University of Jerusalem, Israel

*Correspondence:

Peter M. Kopittke

p.kopittke@uq.edu.au

Specialty section:

This article was submitted to

Plant Nutrition,

a section of the journal

Frontiers in Plant Science

Received: 12 November 2017 Accepted: 12 December 2017

Published: 21 December 2017

Citation:

Kopittke PM, Gianoncelli A,

Kourousias G, Green K and McKenna BA (2017) Alleviation of Al

Toxicity by Si Is Associated with the Formation of Al-Si Complexes

in Root Tissues of Sorghum.

Front. Plant Sci. 8:2189.

doi: 10.3389/fp/s.2017.02189

\section{Alleviation of Al Toxicity by Si Is Associated with the Formation of Al-Si Complexes in Root Tissues of Sorghum}

\author{
Peter M. Kopittke ${ }^{1 *}$, Alessandra Gianoncelli2, George Kourousias ${ }^{2}, K^{2}$ thryn Green ${ }^{3}$ and \\ Brigid A. McKenna ${ }^{1}$
}

${ }^{1}$ School of Agriculture and Food Sciences, The University of Queensland, Brisbane, QLD, Australia, ${ }^{2}$ Elettra Sincrotrone Trieste, Trieste, Italy, ${ }^{3}$ Centre for Microscopy and Microanalysis, The University of Queensland, Brisbane, QLD, Australia

Silicon is reported to reduce the toxic effects of $\mathrm{Al}$ on root elongation but the in planta mechanism by which this occurs remains unclear. Using seedlings of soybean (Glycine max) and sorghum (Sorghum bicolor), we examined the effect of up to $2 \mathrm{mM} \mathrm{Si}$ on root elongation rate (RER) in Al-toxic nutrient solutions. Synchrotron-based low energy $\mathrm{X}$-ray fluorescence (LEXRF) was then used for the in situ examination of the distribution of $\mathrm{Al}$ and $\mathrm{Si}$ within cross-sections cut from the apical tissues of sorghum roots. The addition of Si potentially increased RER in Al-toxic solutions, with RER being up to ca. $0.3 \mathrm{~mm} \mathrm{~h}^{-1}$ (14\%) higher for soybean and ca. $0.2 \mathrm{~mm} \mathrm{~h}^{-1}$ (17\%) higher for sorghum relative to solutions without added Si. This improvement in RER could not be attributed to a change in Al-chemistry of the bulk nutrient solution, nor was it due to a change in the concentration of $\mathrm{Al}$ within the apical $(0-10 \mathrm{~mm})$ root tissues. Using LEXRF to examine sorghum, it was demonstrated that in roots exposed to both $\mathrm{Al}$ and $\mathrm{Si}$, much of the Al was co-located with Si in the mucigel and outer apoplast. These observations suggest that $\mathrm{Si}$ reduces the toxicity of $\mathrm{Al}$ in planta through formation of $\mathrm{Al}-\mathrm{Si}$ complexes in mucigel and outer cellular tissues, thereby decreasing the binding of Al to the cell wall where it is known to inhibit wall loosening as required for cell elongation.

Keywords: aluminum toxicity, alleviation, root elongation, silicon, sorghum, soybean

\section{INTRODUCTION}

Aluminum (Al) is the most common metallic element in the earth's soils (Lindsay, 1979), but at neutral and near-neutral $\mathrm{pH}$ values, $\mathrm{Al}$-containing minerals are of low solubility and are not toxic. However, an estimated $30-40 \%$ of all arable soils worldwide are acid (von Uexküll and Mutert, 1995; Eswaran et al., 1997), with the solubility of Al being elevated in these acid soils. It has been known for ca. 100 years that elevated levels of soluble $\mathrm{Al}$ are highly toxic to plant roots (Veitch, 1904; Daikuhara, 1914), reducing root elongation within 5 min by binding strongly to the cell wall and inhibiting loosening (Kopittke et al., 2015). Yet, despite being the most studied trace element in the field of phytotoxicity, much remains unknown regarding the toxic effects of Al.

Silicon, the second most abundant element in the earth's crust, is regarded as a beneficial element for plant growth (Broadley et al., 2012). Indeed, Si has been shown to enhance resistance to pests and to a range of diseases caused by fungi and bacteria. It has been proposed that this increased resistance is due to a physical effect, with Si forming a layer which impedes penetration 
by the pest (Broadley et al., 2012). Furthermore, Si has been shown to have a beneficial effect in enhancing resistance and tolerance to various forms of abiotic stress, including salinity, drought, metal toxicity, and temperature stress (Haynes, 2017). It has also been reported that $\mathrm{Si}$ alleviates $\mathrm{Al}$ toxicity in a range of plant species, including maize (Zea mays) (Wang et al., 2004), cotton (Gossypium hirsutum) (Li et al., 1989), wheat (Triticum aestivum) (Cocker et al., 1998b), sorghum (Sorghum bicolor) (Galvez et al., 1987; Hodson and Sangster, 1993), and soybean (Glycine max) (Baylis et al., 1994). Three potential mechanisms have been suggested whereby $\mathrm{Si}$ has been observed to improve growth in Al-containing solutions (Cocker et al., 1998a). Firstly, in some studies conducted in nutrient solutions, $\mathrm{Si}$ (added as sodium metasilicate, for example) was added to solutions already containing $\mathrm{Al}$, with this addition of $\mathrm{Si}$ resulting in an increase in solution $\mathrm{pH}$ and the precipitation of $\mathrm{Al}$ hydroxides (Li et al., 1996). Secondly, it is also possible that the bioavailability of $\mathrm{Al}$ can be reduced directly due to the formation of aluminosilicate complexes within the nutrient solution itself (for example, progressive precipitation of aluminosilicate species) (Barcelo et al., 1993). Finally, some studies have shown that the $\mathrm{Si}$ can detoxify $\mathrm{Al}$ in planta independent of any changes in $\mathrm{Al}$ chemistry within the bulk nutrient solution (Cocker et al., 1998b). It is this final (in planta) mechanism which is of interest in the present study. However, there remains some uncertainty as to how $\mathrm{Si}$ alleviates $\mathrm{Al}$ toxicity. One potential mechanism by which $\mathrm{Si}$ could alleviate $\mathrm{Al}$ toxicity is through the precipitation of aluminosilicate complexes within the plant tissues themselves (Hodson and Evans, 1995; Cocker et al., 1998a; Liang et al., 2001, 2015).

The aim of the present study was to investigate the impact of Si on Al toxicity utilizing seedlings of soybean and sorghum. The effect on Si on root elongation rate (RER) was quantified in Al-toxic nutrient solutions, with changes in soluble (reactive) $\mathrm{Al}$ determined colorimetrically. We also used synchrotron-based low energy X-ray fluorescence (LEXRF) to provide information on the cellular and subcellular distribution of $\mathrm{Al}$ and $\mathrm{Si}$ in root tissues. Due to the ubiquitous nature of Si in soils (Wolt, 1994), gaining an understanding of how Si potentially alleviates $\mathrm{Al}$ toxicity is important given that an estimated $30-40 \%$ of all arable soils worldwide are acid.

\section{MATERIALS AND METHODS}

\section{General Experimental Procedures}

Seeds of soybean (cv. Bunya) and sorghum (cv. SF Flourish) were rolled in paper towel and suspended vertically in tap water for either 3 days (soybean) or 2 days (sorghum). Perspex strips, each with seven seedlings, were placed on top of glass beakers containing $650 \mathrm{~mL}$ of deionized water with $1 \mathrm{mM} \mathrm{CaCl}_{2}$ and $5 \mu \mathrm{M} \mathrm{H}_{3} \mathrm{BO}_{3}$. Throughout this experiment, we used simple nutrient solutions rather than complete nutrient solutions, as for the examination of Al toxicity, the use of simple nutrient solutions reduces the complexity and uncertainty of Al speciation (Kinraide et al., 1985; Kopittke and Blamey, 2016). However, at a minimum, nutrient solutions must contain $\mathrm{Ca}$ and $\mathrm{B}$ given that root elongation is inhibited rapidly in their absence due to their low phloem mobility (Kinraide et al., 1985; Goldbach et al., 2001). After $18 \mathrm{~h}$ growth in these basal solutions, the seedlings in the Perspex strips were photographed using a digital camera to allow for later measurement of root length before being placed on new beakers containing the treatment solution (see below). The seedlings were photographed after growth for a further 3, 6 , $12,24,36$, and $48 \mathrm{~h}$, with root lengths measured digitally using ImageJ v1.45s ${ }^{1}$. All plant-growth solutions were continuously aerated.

Experiment 1 aimed to provide initial data on the effect of $\mathrm{Si}$ on $\mathrm{Al}$ toxicity across a range of $\mathrm{Al}$ and $\mathrm{Si}$ concentrations and $\mathrm{pH}$ values. Given that deionized water may contain trace levels of $\mathrm{Si}$ as an impurity (for example, see Rogalla and Romheld, 2002), treatments to which Si were not added (i.e., nominally $0 \mu \mathrm{M}$ $\mathrm{Si})$ are referred to as '-Si' hereafter. For soybean, 32 treatments were investigated, with four $\mathrm{Al}$ concentrations (see below), four $\mathrm{Si}$ concentrations (-Si, $0.1,1$, and $2 \mathrm{mM}$ ), and two $\mathrm{pH}$ values (4.5 and 5.0), each with three replicates. For sorghum, only a single $\mathrm{pH}$ value (4.5) was examined (see section "Results"), with 16 treatments thereby consisting of four $\mathrm{Al}$ concentrations (below) with four Si concentrations (-Si, $0.1,1$, and $2 \mathrm{mM}$ ), each with three replicates. In addition to a Control $(0 \mu \mathrm{M} \mathrm{Al})$, the $\mathrm{Al}$ was supplied at concentrations sufficient to reduce RER by ca. 25,50 , and $75 \%$ over $48 \mathrm{~h}$, being $0,5,10$, and $30 \mu \mathrm{M} \mathrm{Al}$ for soybean and $0,5,10$, and $25 \mu \mathrm{M} \mathrm{Al}$ for sorghum. These $\mathrm{Al}$ concentrations had been determined from preliminary experiments. Concentrations of Si higher than $2 \mathrm{mM}$ were not investigated as they are not representative of typical soil solutions (Menzies and Bell, 1988; Wolt, 1994). To prepare the treatment solutions, sufficient $\mathrm{Na}_{2} \mathrm{O}_{3}$ Si. $9 \mathrm{H}_{2} \mathrm{O}$ was dissolved in deionized water with $19 \mathrm{M} \mathrm{HCl}$ added to decrease to $\mathrm{pH}$ 5.4. For example, to prepare $1 \mathrm{~L}$ of solution with $1 \mathrm{mM}$ Si required $0.284 \mathrm{~g}$ of $\mathrm{Na}_{2} \mathrm{O}_{3} \mathrm{Si} .9 \mathrm{H}_{2} \mathrm{O}$ and ca. $0.34 \mathrm{~mL}$ of $19 \mathrm{M} \mathrm{HCl}$. Next, Ca, B, and $\mathrm{Al}$ were added using stock solutions of $0.65 \mathrm{M} \mathrm{CaCl}_{2}, 3.25 \mathrm{mM} \mathrm{H}_{3} \mathrm{BO}_{3}$, and $10 \mathrm{mM}$ $\mathrm{AlCl}_{3} \cdot 6 \mathrm{H}_{2} \mathrm{O}$. Finally, $0.1 \mathrm{M} \mathrm{HCl}$ was used to adjust $\mathrm{pH}$ to the desired value (i.e., either 4.5 or 5.0). Solutions were analyzed to determine the $\mathrm{Al}$ concentration, with $10 \mathrm{~mL}$ samples collected at the time of transfer (i.e., $0 \mathrm{~h}$ ) and after $48 \mathrm{~h}$ before being filtered ( $0.22 \mu \mathrm{m}$, Millipore), acidified with $20 \mu \mathrm{L}$ of concentrated $\mathrm{HCl}$, refrigerated at $4^{\circ} \mathrm{C}$, and analyzed using inductively coupled plasma optical emission spectroscopy (ICP-OES). Data for RER were analyzed using a two-way analysis of variance (GenStat v18), with comparisons between means made using Fisher's protected least significant difference (LSD) test.

Experiment 2 aimed to provide more detailed information for some of the treatments identified in Experiment 1 found to alleviate the toxic effects of Al. For soybean, a total of seven treatments were investigated at $\mathrm{pH} 4.5$, with six $\mathrm{Al}$ concentrations $(0,5,10,15,20$, and $30 \mu \mathrm{M} \mathrm{Al})$ without added Si (i.e., -Si) plus one $\mathrm{Al}$ concentration $(30 \mu \mathrm{M})$ at $2 \mathrm{mM} \mathrm{Si}$. For sorghum, a total of eight treatments were investigated at $\mathrm{pH} 4.5$, with six $\mathrm{Al}$ concentrations $(0,2.5,5,10,15$, and $25 \mu \mathrm{M} \mathrm{Al})$ without added $\mathrm{Si}$ (i.e., -Si) plus two $\mathrm{Al}$ concentrations $(10$ and $25 \mu \mathrm{M})$ at $2 \mathrm{mM}$ Si. All treatments were replicated five times. For assessment of the

\footnotetext{
${ }^{1}$ http://imagej.nih.gov/ij/
} 
concentration of inorganic monomeric $\mathrm{Al}$ concentrations after 0 , 24 , and $48 \mathrm{~h}$, the pyrocatechol violet (PCV) method was used as described by Kerven et al. (1989). Briefly, $3.0 \mathrm{~mL}$ of sample was pipetted into a vial, with $0.20 \mathrm{~mL}$ of $0.0375 \%$ PCV reagent added, followed by $1.0 \mathrm{~mL}$ of hexamine buffer (prepared as described by Kerven et al., 1989). Absorbance at $585 \mathrm{~nm}$ was measured after 60 s (UV-2600, Shimadzu, Japan). We also used PhreeqcI 3.1.7 (Parkhurst, 2014) to examine the potential formation of aqueous $\mathrm{AlH}_{3} \mathrm{SiO}_{4}^{2+}$ (Nordstrom and May, 1996; Pokrovski et al., 1996) using values given in Table 1. Data for RER were analyzed using regression analysis with a Weibull-type function (Taylor et al., 1991).

\section{Measurement of Bulk Al Concentrations in Apical Root Tissues}

Bulk concentrations of $\mathrm{Al}$ in the root apical tissues were determined for both soybean and sorghum in solutions at $\mathrm{pH}$ 4.5. For soybean, the experiment consisted of seven treatments, with six of these seven treatments without added $\mathrm{Si}$ (i.e., -Si) (0, $5,10,15,20$, and $30 \mu \mathrm{M} \mathrm{Al}$ ) and one treatment containing $2 \mathrm{mM}$ Si $(30 \mu \mathrm{M} \mathrm{Al})$. For sorghum, the experiment consisted of eight treatments, with six $\mathrm{Al}$ concentrations without added $\mathrm{Si}$ (i.e., - $\mathrm{Si}$ ) $(0,2.5,5,10,15$, and $25 \mu \mathrm{M} \mathrm{Al})$ plus two $\mathrm{Al}$ concentrations at $2 \mathrm{mM}$ Si $(10$ and $25 \mu \mathrm{M})$. Each treatment consisted of 75 seedlings suspended above $20 \mathrm{~L}$ of nutrient solution containing $1 \mathrm{mM} \mathrm{CaCl}_{2}$ and $5 \mu \mathrm{M} \mathrm{H}_{3} \mathrm{BO}_{3}$ at $\mathrm{pH}$ 4.5. The seedlings were grown in this basal solution for $24 \mathrm{~h}$ before being moved to new $20 \mathrm{~L}$ containers with the Al-containing treatments. The PCV method was used to measure inorganic monomeric Al concentrations after 0,24 , and $48 \mathrm{~h}$. After being exposed to the treatment solutions for $48 \mathrm{~h}$, the seedlings were rinsed in $1 \mathrm{mM}$ $\mathrm{CaCl}_{2}$ before the apical tissues $(0-10 \mathrm{~mm})$ were excised, briefly placed on filter paper to remove excess moisture, weighed to obtain fresh mass, and dried at $65^{\circ} \mathrm{C}$. Tissues were digested using hydrofluoric acid dissolution (Saito et al., 2005) and analyzed for Al using ICP-OES.

\section{In Situ Analyses of the Distribution of Al in Root Apices}

An experiment was conducted to investigate the distribution of $\mathrm{Al}$ and $\mathrm{Si}$ in root apices of sorghum on a cellular and subcellular scale. Sorghum seedlings were grown for $18 \mathrm{~h}$ in basal solutions $\left(1 \mathrm{mM} \mathrm{CaCl}_{2}\right.$ and $5 \mu \mathrm{M} \mathrm{H}_{3} \mathrm{BO}_{3}$ ) at $\mathrm{pH} 4.5$ before being transferred to solutions containing $1 \mathrm{mM} \mathrm{CaCl}_{2}, 5 \mu \mathrm{M} \mathrm{H}_{3} \mathrm{BO}_{3}$,

TABLE 1 | Thermodynamic constants used to predict the formation of potential formation of soluble $\mathrm{AlH}_{3} \mathrm{SiO}_{4}^{2+}$ using Phreeqcl 3.1.7 (Parkhurst, 2014).

\begin{tabular}{ll}
\hline & $\log \boldsymbol{K}$ \\
\hline $\mathrm{Al}^{3+}+\mathrm{H}_{4} \mathrm{SiO}_{4}^{0} \rightleftharpoons \mathrm{AlH}_{3} \mathrm{SiO}_{4}^{2+}+\mathrm{H}^{+}$ & -2.38 \\
$\mathrm{Al}^{3+}+\mathrm{H}_{2} \mathrm{O} \rightleftharpoons \mathrm{AlOH}{ }^{2+}+\mathrm{H}^{+}$ & -5.00 \\
$\mathrm{Al}^{3+}+2 \mathrm{H}_{2} \mathrm{O} \rightleftharpoons \mathrm{Al}(\mathrm{OH})_{2}^{+}+2 \mathrm{H}^{+}$ & -10.1 \\
$\mathrm{Al}^{3+}+3 \mathrm{H}_{2} \mathrm{O} \rightleftharpoons \mathrm{Al}(\mathrm{OH})_{3}^{0}+3 \mathrm{H}^{+}$ & -16.8 \\
$\mathrm{Al}^{3+}+4 \mathrm{H}_{2} \mathrm{O} \rightleftharpoons \mathrm{Al}(\mathrm{OH})_{4}^{-}+4 \mathrm{H}^{+}$ & -22.99 \\
\hline
\end{tabular}

Values were taken from Nordstrom and May (1996) and Pokrovski et al. (1996).
$25 \mu \mathrm{M} \mathrm{Al}$, and either -Si or $2 \mathrm{mM}$ Si. After growth for $48 \mathrm{~h}$ in these Al-containing solutions, roots were briefly rinsed in $1 \mathrm{mM} \mathrm{CaCl} 2$ ( $\mathrm{pH} 4.5$ ) and a $200-\mu \mathrm{m}$ transverse section was cut $5 \mathrm{~mm}$ from the apex (this corresponding to the elongation zone). The sections were placed in planchettes filled with hexadecane, and frozen in a high pressure freezer (Leica EM PACT2 with a Leica EM RTS). The high pressure freezing was used to ensure rapid freezing, which occurs within milliseconds. The planchettes were split apart and stored under liquid nitrogen before freeze substitution (Leica EM AFS2) in $2 \%(\mathrm{v} / \mathrm{v})$ glutaraldehyde in acetone at $-90^{\circ} \mathrm{C}$ for $48 \mathrm{~h}$, warming to $20^{\circ} \mathrm{C}$, washing in ethanol, infiltration with LR White Resin, and polymerization. After storage at ambient temperature, a Reichert Ultracut Microtome was used to cut 5$\mu \mathrm{m}$ thick sections, which were placed on $4-\mu \mathrm{m}$ thick Ultralene Film.

The LEXRF measurements were conducted using the TwinMic beamline (Gianoncelli et al., 2016) at ELETTRA (BL 1.1L) which has eight Si-drift detectors in an annular back-scattering configuration positioned around the specimen (Gianoncelli et al., 2009). In LEXRF mode, the selected regions were scanned with $1.7 \mathrm{keV}$ excitation energy with a $0.6 \mu \mathrm{m}$ step size (pixel) and a dwell time of $8 \mathrm{~s}$ per pixel. Each individual map was $60 \mu \mathrm{m} \times 60 \mu \mathrm{m}(100 \times 100$ pixels $)$ with scans taking ca. $22 \mathrm{~h}$ to complete. Given that the diameter of the root cylinder was ca. $0.5 \mathrm{~mm}$, it was possible to scan only a small proportion of the total cross-sectional area. For each sample, the area selected to be scanned $(60 \mu \mathrm{m} \times 60 \mu \mathrm{m})$ was the rhizodermis and outer cortex - this being the area in which $\mathrm{Al}$ initially accumulates and where $\mathrm{Al}$ is known to rapidly exert its toxic effect (Lazof et al., 1996; Marienfeld et al., 2000; Kopittke et al., 2015). The LEXRF spectra were fitted using PyMCA v4.7.3 (Sole et al., 2007). It was because of the long scan duration (ca. $22 \mathrm{~h}$ per scan) that only sorghum was examined by LEXRF, with insufficient time to also examine soybean. Furthermore, although it is known that $\mathrm{Si}$ can accumulate at the endodermis in roots of sorghum (Sangster and Parry, 1976; Hodson and Sangster, 1993), we only examined the rhizodermis and outer cortex in the present study given that this is where $\mathrm{Al}$ accumulates (and we were interested in $\mathrm{Al}-\mathrm{Si}$ interactions) and we had only limited beamtime.

\section{RESULTS}

\section{Effects of Si on Root Elongation Rate and Soluble Al}

Experiment 1 aimed to examine the effect of $\mathrm{Si}$ on the rhizotoxicity of $\mathrm{Al}$ by examining a range of $\mathrm{Al}$ and $\mathrm{Si}$ concentrations at two $\mathrm{pH}$ values. In all three instances, the interaction between $\mathrm{Al}$ and $\mathrm{Si}$ was not significant $(P>0.05)$, indicating that the pattern of change in RER upon the addition of $\mathrm{Si}$ was similar regardless of the $\mathrm{Al}$ concentration (Figure 1). Thus, the LSD values presented allow comparison between the different $\mathrm{Si}$ concentrations at any given $\mathrm{Al}$ concentration. As expected, the extent to which Si alleviated Al toxicity increased with increasing Si concentration. Indeed, at $\mathrm{pH} 4.5$, the addition of $0.1 \mathrm{mM}$ Si typically did not significantly improve growth in Altoxic solutions (other than for $10 \mu \mathrm{M} \mathrm{Al}$ for sorghum, Figure 1B), 

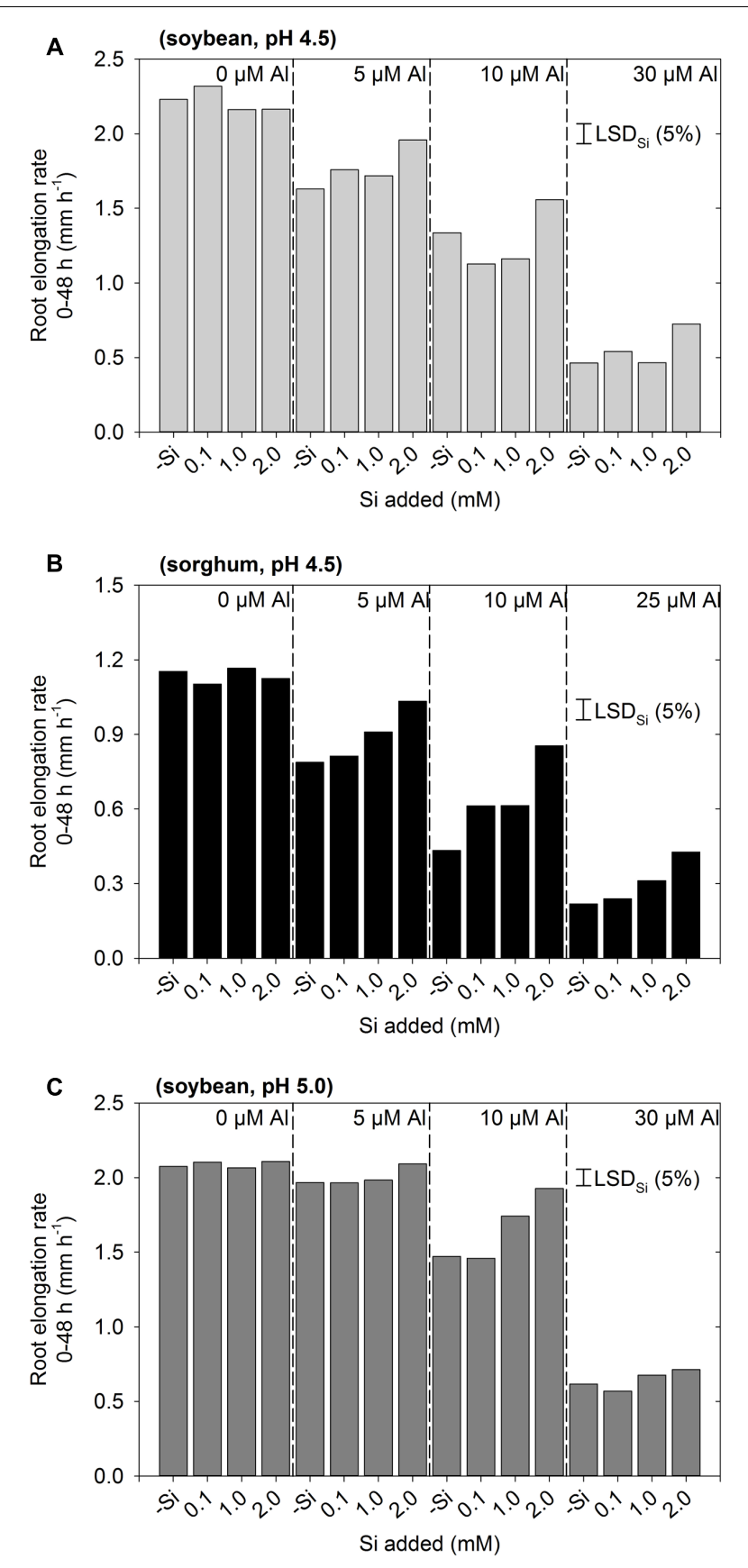

FIGURE 1 | Effect of $\mathrm{Al}$ and Si on root elongation rate of (A) soybean in solutions at $\mathrm{pH} 4.5$, (B) sorghum in solutions at $\mathrm{pH} 4.5$, and (C) soybean in solutions at $\mathrm{pH} 5.0$ (Experiment 1). The concentrations listed for $\mathrm{Al}$ and $\mathrm{Si}$ are nominal and were not measured. In all instances, the interaction between Al and Si was not significant, with the LSD values presented enabling the comparison between Si concentrations at any given Al concentration.

whilst $2 \mathrm{mM}$ Si significantly improved growth in all Al-toxic solutions at $\mathrm{pH} 4.5$ by ca. $0.2-0.4 \mathrm{~mm} \mathrm{~h}^{-1}$ (Figures 1A,B). For roots of soybean grown at $\mathrm{pH} 5.0$, it was noted that $\mathrm{Al}$ was less toxic than at $\mathrm{pH} 4.5$, even in the absence of Si (Figure 1C). For example, for soybean grown at $\mathrm{pH} 4.5$, the addition of
$5 \mu \mathrm{M} \mathrm{Al}(-\mathrm{Si})$ resulted in a decrease in RER from 2.2 to $1.6 \mathrm{~mm} \mathrm{~h}^{-1}$, yet at $\mathrm{pH} 5.0 \mathrm{RER}$ was $2.1 \mathrm{~mm} \mathrm{~h}^{-1}$ at $0 \mu \mathrm{M} \mathrm{Al}$ and $2.0 \mathrm{~mm} \mathrm{~h}^{-1}$ at $5 \mu \mathrm{M} \mathrm{Al}$ (Figure 1C). The improved root growth at $\mathrm{pH} 5.0$ is presumably due to the precipitation of $\mathrm{Al}$ in these supersaturated solutions (see modeling of Kopittke and Blamey, 2016), and so these seemingly unstable solutions at $\mathrm{pH}$ 5.0 were not investigated further. Based upon these results from Experiment 1 (Figure 1), three Si-containing treatments were selected for further investigation, being soybean with $30 \mu \mathrm{M}$ Al plus $2 \mathrm{mM} \mathrm{Si}$, and sorghum with either 10 or $25 \mu \mathrm{M}$ plus $2 \mathrm{mM} \mathrm{Si}$.

Experiment 2 aimed to provide more detailed information on the ability of Si to alleviate Al toxicity. Again, the addition of $2 \mathrm{mM} \mathrm{Si}$ was found to alleviate the toxic effects of $\mathrm{Al}$, with RER being ca. $0.3 \mathrm{~mm} \mathrm{~h}^{-1}$ higher for soybean and ca. $0.2 \mathrm{~mm} \mathrm{~h}^{-1}$ higher for sorghum relative to values calculated from the regression in Si-free solutions (Figure 2). Using sorghum as an example, it was observed that RER in a solution with $25 \mu \mathrm{M}$ $\mathrm{Al}$ and $2 \mathrm{mM} \mathrm{Si}\left(0.41 \mathrm{~mm} \mathrm{~h}^{-1}\right)$ was comparable to that predicted for a solution with $13 \mu \mathrm{M} \mathrm{Al}$ and without added Si (as calculated from the regression, see dotted line in Figure 2B). Similar results were also observed for soybean (Figure 2A).

To determine if this improved growth in Si-containing solutions resulted from a decrease in soluble $\mathrm{Al}$ due to the precipitation of aluminosilicate complexes within the bulk nutrient solution, inorganic monomeric $\mathrm{Al}$ concentrations were measured using the PCV method. Averaged across the $48 \mathrm{~h}$ experimental period, measured $\mathrm{Al}$ concentrations in $\mathrm{Si}$-free solutions were an average of $12 \%$ lower than the nominal concentrations, whilst measured $\mathrm{Al}$ concentrations in the three solutions with $2 \mathrm{mM}$ Si were an average of $10 \%$ lower than nominal concentrations (Figure 2). Thus, changes in RER upon the addition of $\mathrm{Si}$ were could not be attributed to changes in soluble $\mathrm{Al}$ concentrations. To further investigate potential changes in the $\mathrm{Al}$ chemistry of soluble $\mathrm{Al}$ in the bulk nutrient solution, we also modeled the potential formation of aqueous $\mathrm{AlH}_{3} \mathrm{SiO}_{4}^{2+}$ using PhreeqcI (Table 1), with the magnitude of its formation predicted to be comparatively small. For example, for a solution containing $30 \mu \mathrm{M} \mathrm{Al}$ and $2 \mathrm{mM} \mathrm{Si}$, aqueous $\mathrm{AlH}_{3} \mathrm{SiO}_{4}^{2+}$ was predicted to have a concentration of $3.8 \mu \mathrm{M}$, with the predicted concentration of $\mathrm{Al}^{3+}$ concomitantly reducing from $23 \mu \mathrm{M}(-\mathrm{Si})$ to $21 \mu \mathrm{M}$ ( $2 \mathrm{mM} \mathrm{Si}$ ). However, it should be noted that there is considerable uncertainty regarding the equilibrium constant for $\mathrm{AlH}_{3} \mathrm{SiO}_{4}^{2+}$ (Browne and Driscoll, 1992; Pokrovski et al., 1996).

\section{Effects of $\mathrm{Si}$ on Concentrations of $\mathrm{Al}$ in Root Apical Tissues}

In the absence of $\mathrm{Si}$, concentrations of $\mathrm{Al}$ in the apical root tissues $(0-10 \mathrm{~mm})$ increased with increasing $\mathrm{Al}$ in the nutrient solution (Figure 3). Although this was observed for both plant species, tissue $\mathrm{Al}$ concentrations were ca. threefold higher in soybean than in sorghum. Importantly, for the Si-containing nutrient solutions, tissue $\mathrm{Al}$ concentrations were similar to those grown in the corresponding Si-free nutrient solutions (Figure 3). 

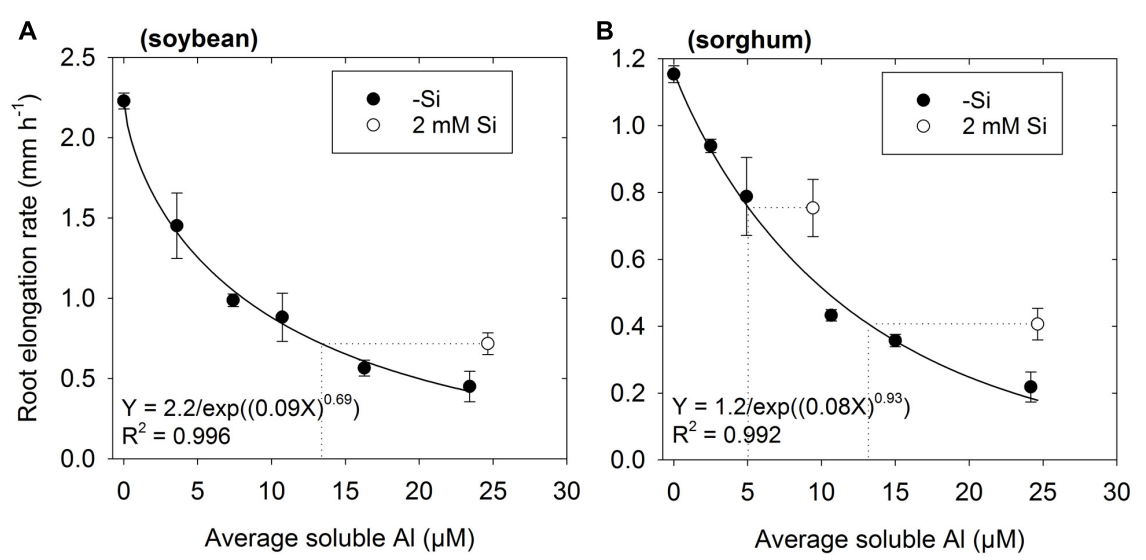

FIGURE 2 | Effect of Al on root elongation rate (RER) of (A) soybean and (B) sorghum over 48 h exposure with either no added Si (-Si) or 2 mM Si at pH 4.5 (Experiment 2). Soluble Al concentrations are the average of values measured using the PCV method after 0, 24, and 48 h. The regression (Taylor et al., 1991) is fitted only to treatments with $0 \mu \mathrm{M}$ Si. The dotted lines are shown for seedlings grown in solutions containing Si. These dotted lines show the predicted soluble Al concentration for a Si-free solution that corresponds to the same RER as observed in the solution containing Si.
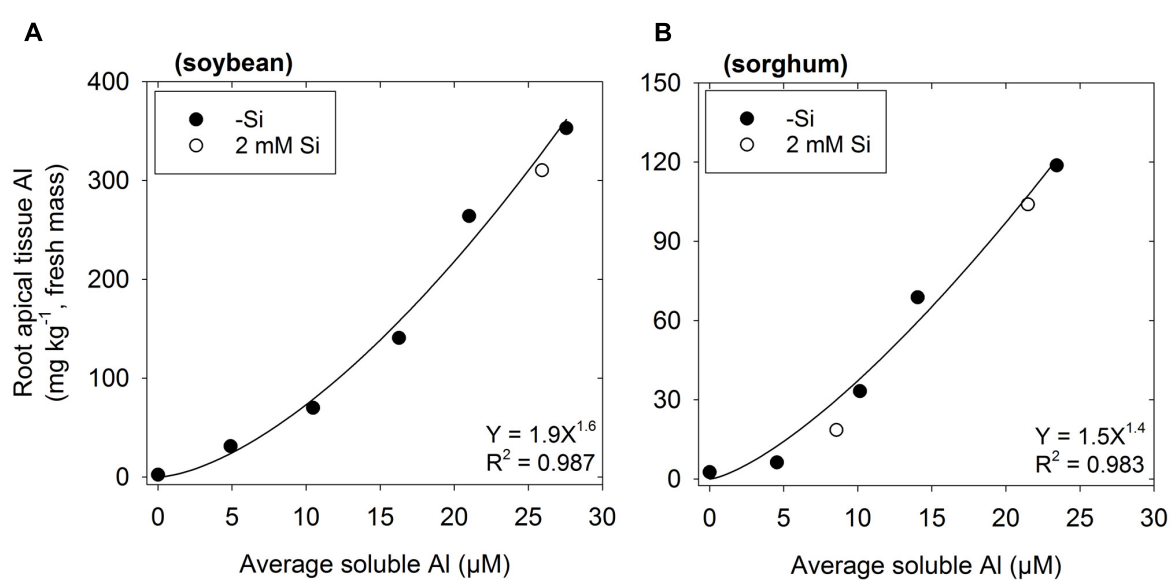

FIGURE 3 | Effect of $\mathrm{Al}$ on the concentration of $\mathrm{Al}$ in the root apical tissues (0-10 $\mathrm{mm})$ of $\mathbf{( A )}$ soybean and (B) sorghum. Soluble Al concentrations are the average of values measured using the PCV method after 0,24 , and $48 \mathrm{~h}$. The regression is fitted only to treatments with no added $\mathrm{Si}(-\mathrm{Si})$.

\section{In Situ Analyses of Al Distribution in Root Apical Tissues}

To examine the cellular and subcellular distribution of $\mathrm{Al}$ and $\mathrm{Si}$ within the rhizodermis and outer cortex of the apical root tissues (5 $\mathrm{mm}$ from the apex) of sorghum, we utilized synchrotronbased LEXRF. In the absence of added $\mathrm{Si}, \mathrm{Al}$ accumulated predominately in the cell walls (Figures $4 \mathbf{A}, \mathbf{B}$ ). In the presence of $2 \mathrm{mM} \mathrm{Si}, \mathrm{Al}$ was again observed to accumulate in the cell walls, but some of this Al was co-located with high concentrations of $\mathrm{Si}$ (Figures 4C-F). These Al-Si complexes appeared to form either within the mucigel or in the outer apoplast at the rootsolution interface, being associated both with the rhizodermis (Figures 4C,D) and with the border cells (Figures 4E,F).

Using the data from the LEXRF analyses, elemental correlation was examined to determine the relationship between $\mathrm{Al}$ and $\mathrm{Si}$ (if any). Unsurprisingly, in the absence of added $\mathrm{Si}$, there was no relationship evident between $\mathrm{Al}$ and $\mathrm{Si}$ within the root tissues, with $\mathrm{Si}$ intensity being low for all pixels (Figure 5A). In contrast, in the presence of $2 \mathrm{mM} \mathrm{Si}$, it was apparent that there were three different pixel 'populations', as shown in Figure 5B for example by the dashed ovals. For some pixels, although $\mathrm{Al}$ intensity was high, Si intensity remained low (blue dashed oval in Figure 5B). Conversely, some pixels had a low Al intensity but a high $\mathrm{Si}$ intensity (black dashed oval in Figure 5B, but also see Figure 5C). Finally, for some pixels, the intensity of both $\mathrm{Al}$ and $\mathrm{Si}$ was high, indicating the co-localization of these elements (red dashed oval in Figure 5B, but also see Figure 5C). Importantly, this increase with $\mathrm{Si}$ with increasing $\mathrm{Al}$ (red dashed oval in Figure 5B) was approximately linear.

\section{DISCUSSION}

We found that the addition of Si partially alleviated the toxic effects of $\mathrm{Al}$ in both soybean and sorghum (Figures 1A,B, 2). 

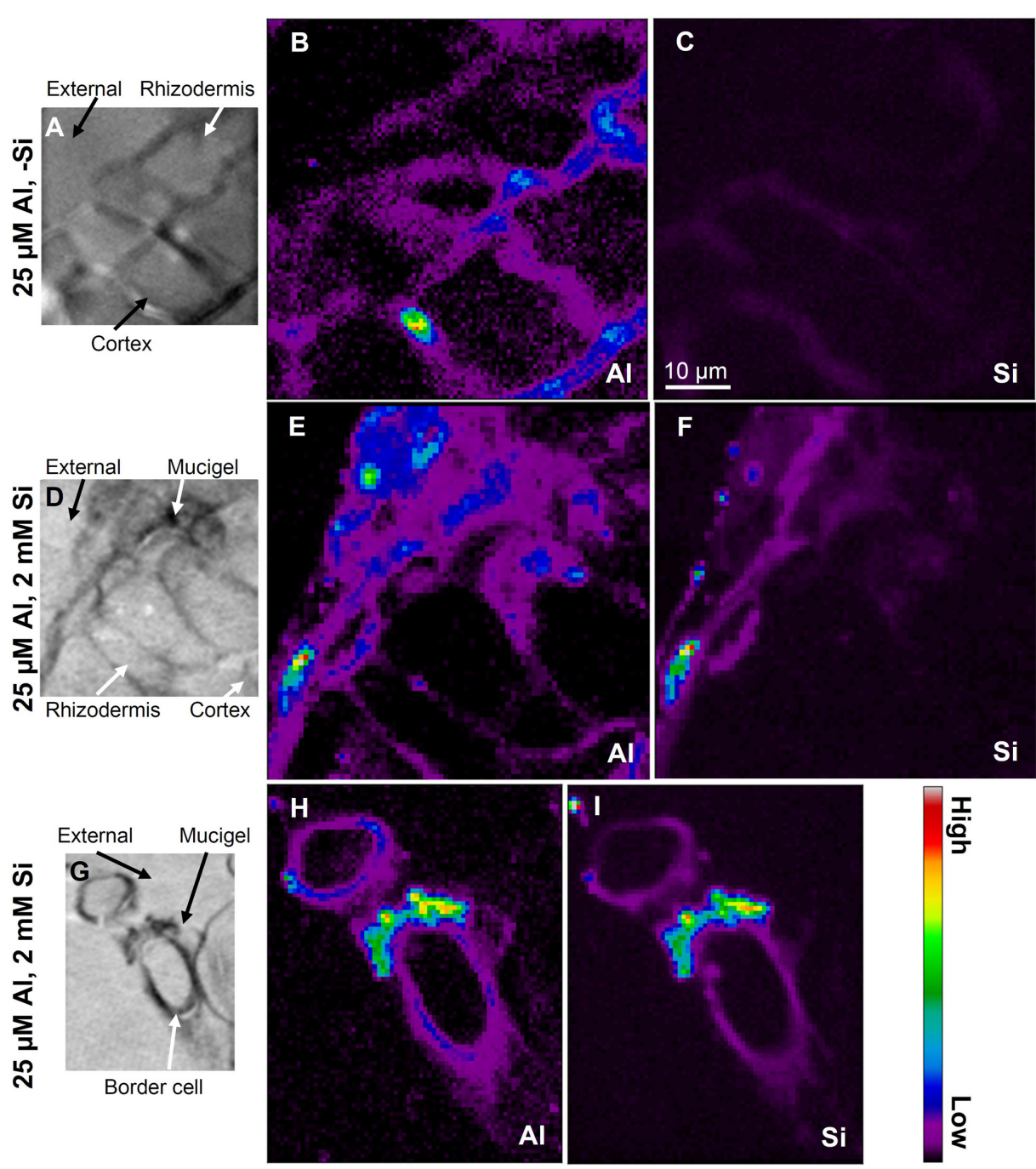

FIGURE 4 | Distribution of $\mathrm{Al}$ and Si using LEXRF in 5 - $\mu \mathrm{m}$-thick transverse sections of sorghum roots ( $5 \mathrm{~mm}$ from the apex) exposed to solutions nominally containing either $25 \mu \mathrm{M} \mathrm{Al}$ (A-C) or $25 \mu \mathrm{M} \mathrm{Al}$ with $2 \mathrm{mM} \mathrm{Si} \mathrm{(D-I)} \mathrm{for} 48 \mathrm{~h}$. The images in (A,D,G) show the cellular structure, while images in (B,E,H) show the distribution of Al, while images in (C,F,I) show the distribution of Si. In (A-F), the exterior of the root is in the top-left corner, with the rhizodermis (and mucigel) plus 1-2 layers of cortical cells shown. Signal intensity is presented as a color scale, with brighter colors corresponding to higher concentrations. Images have been scaled so that they can be directly compared within each element [i.e., (B) can be compared with (E,H), and (C) can be compared with (F,I)], but not between elements. The scale-bar in (C) applies to all images.

The magnitude of this Si-induced increase in RER in Al-toxic solutions was similar for both plant species, being up to ca. $0.3 \mathrm{~mm} \mathrm{~h}^{-1}$ (14\%) higher for soybean and ca. $0.2 \mathrm{~mm} \mathrm{~h}^{-1}$ (17\%) higher for sorghum relative to solutions without added Si. These findings are in agreement with that reported previously for soybean (Baylis et al., 1994) and sorghum (Galvez et al., 1987; Hodson and Sangster, 1993).

Although the addition of Si partially alleviated the reduction of root elongation in Al-toxic solutions (Figures 1A,B, 2), this improvement in growth could not be attributed to a decrease in soluble $\mathrm{Al}$ in the bulk nutrient solution (Figure 2). Similarly, the improvement in growth could not be attributed to a decrease in the total concentration of $\mathrm{Al}$ in the apical $(0-10 \mathrm{~mm})$ root tissues (Figure 3). Using LEXRF, it was found that $\mathrm{Al}$ (in the absence of added $\mathrm{Si}$ ) accumulated largely within the apoplast a finding in accordance with previous observations in roots of soybean (Kopittke et al., 2015) and Picea abies (Hodson and Wilkins, 1991). For roots exposed to both $\mathrm{Al}$ and $\mathrm{Si}$, the $\mathrm{Al}$ again accumulated in the apoplast, but much of the Al was co-located with $\mathrm{Si}$ both within the mucigel and within the apoplast (Figures 4C-F, 5B,C). We consider it likely that these $\mathrm{Al}-\mathrm{Si}$ complexes within the root tissues were aluminosilicates or hydroxyaluminosilicates, given their low solubility (Lindsay, 1979; Exley and Birchall, 1992), although further work is required in this regard. Thus, the data support the suggestion that $\mathrm{Si}$ alleviates $\mathrm{Al}$ toxicity through the in planta precipitation of $\mathrm{Al}-$ $\mathrm{Si}$ complexes. Given that Al rapidly reduces RER (within $5 \mathrm{~min}$ ) by binding strongly to the cell wall and inhibiting its loosening 

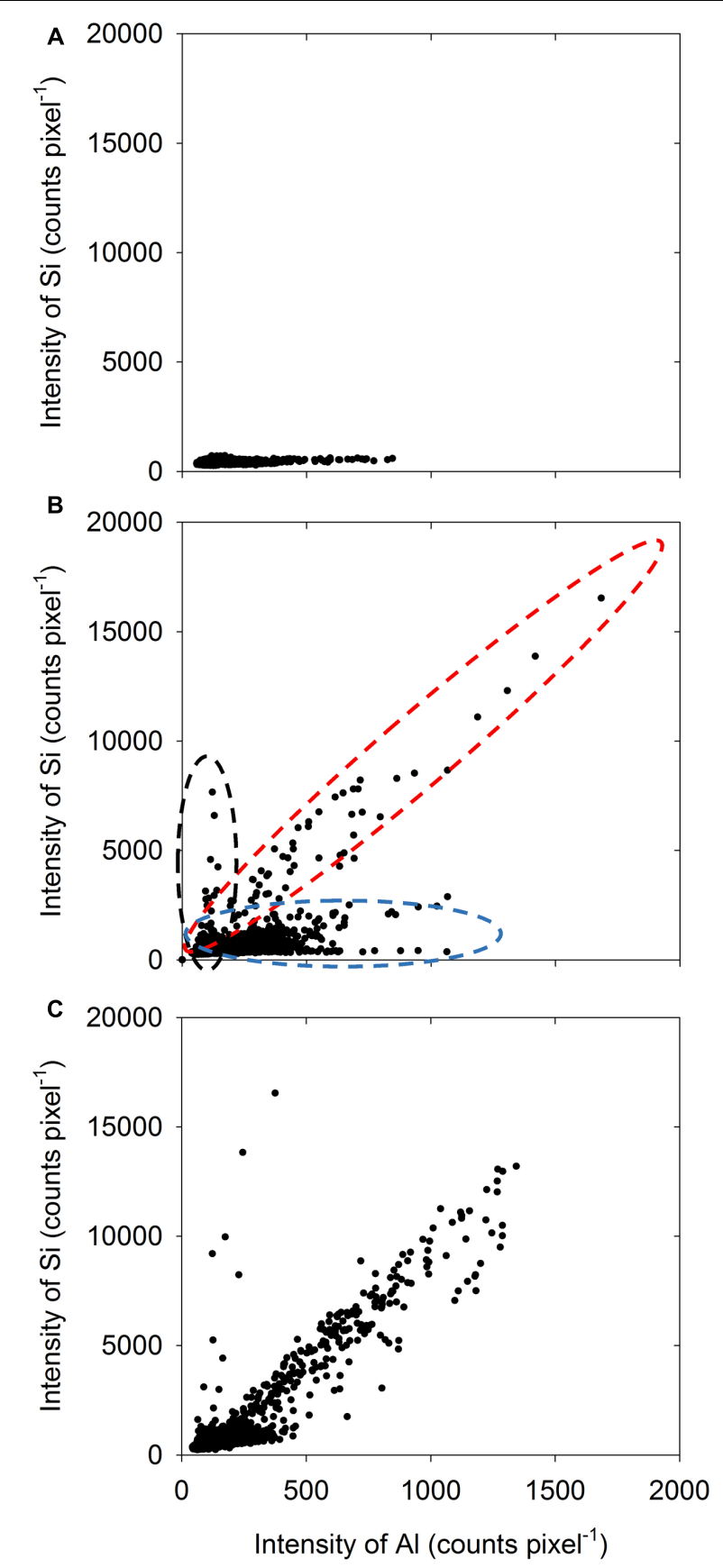

FIGURE 5 | Element correlation plot showing the relationship between Al intensity and Si intensity for 5 - $\mu \mathrm{m}$-thick transverse sections of sorghum roots ( $5 \mathrm{~mm}$ from the apex) examined using LEXRF following exposure to solutions nominally containing either $25 \mu \mathrm{M} \mathrm{Al}$ (A) or $25 \mu \mathrm{M} \mathrm{Al}$ with $2 \mathrm{mM} \mathrm{Si} \mathrm{(B,C)} \mathrm{for}$ $48 \mathrm{~h}$. Data were extracted from the images shown in Figure 4. Across the three samples (A-C), three broad types of populations were observed, as indicated by the three dashed ovals in (B).

(Jones et al., 2006; Horst et al., 2010; Kopittke et al., 2015), we propose that the formation of Al-Si compounds in planta reduces the toxic effects of $\mathrm{Al}$ by reducing its binding to the cell wall. This hypothesis is in accordance with the finding of Prabagar et al. (2011) who, examining suspension cultures of Picea abies, used morin (a fluorochrome) to examine the distribution of $\mathrm{Al}$. Although it is known that morin does not bind to $\mathrm{Al}$ that is already bound strongly to other ligands (such as the cell wall) (Eticha et al., 2005), Prabagar et al. (2011) concluded that the addition of $\mathrm{Si}$ reduced the concentration of free $\mathrm{Al}$ within the cell wall in parallel with its amelioration of Al toxicity.

The magnitude of the improvement in RER upon addition of $\mathrm{Si}$ is in general agreement with previous observations, including in wheat (Cocker et al., 1998b), maize (Wang et al., 2004), and sorghum (Galvez et al., 1987; Hodson and Sangster, 1993) (also see Table 1 of Hodson and Evans, 1995). In addition, our finding that the Si-induced improvement is associated with the formation of Al-Si compounds in the mucigel or within the outer apoplast at the root-solution interface are in general agreement with those of Hodson and Sangster (1993). These authors used electron microscopy to examine roots of sorghum exposed to $100 \mu \mathrm{M} \mathrm{Al}$ and $2800 \mu \mathrm{M}$ Si for 8 days and found Al-Si compounds in the outer tangential wall (i.e., at the root-solution interface). The solution Al concentration of $100 \mu \mathrm{M}$ used by Hodson and Sangster (1993) however, is high relative to that commonly found in solutions of acid soils (Kopittke and Blamey, 2016) and is also high relative to that required to reduce RER in sorghum (Figure 2). It is possible that Hodson and Sangster (1993) used this high $\mathrm{Al}$ concentration due to the comparatively poor sensitivity of the energy-dispersive X-ray spectroscopy that was used to analyze the plant tissues. Our findings are also in agreement with those of Wang et al. (2004), with these authors using a fractionation procedure and reporting that the addition of Si resulted in greater accumulation of $\mathrm{Al}$ in the root cell walls, possibly as aluminosilicates. In contrast, however, the findings of the present study do not seem to be in agreement with Corrales et al. (1997) who, studying maize, found that the addition of Si decreased $\mathrm{Al}$ concentrations in root tissues, with these authors proposing that this decrease in $\mathrm{Al}$ concentration in the root tissue was possibly associated with decreased binding to cell wall through esterification of polyuronides within cell walls (Corrales et al., 1997). Similarly, it was suggested by Kidd et al. (2001) that an enhanced exudation of phenolic compounds may be responsible for $\mathrm{Si}$-induced $\mathrm{Al}$ resistance in maize.

It is useful to consider why these Al-Si compounds formed within the mucigel or apoplast but not in the bulk nutrient solution (which would have resulted in a decrease in the inorganic monomeric Al concentration). Firstly, it is known that the mucigel is a highly negatively charged polysaccharide (having the highest negative charge of any portion of the root) as is the cell wall (Oades, 1978; Haynes, 1980). Therefore, the observed binding of $\mathrm{Al}$ to the mucigel and cell wall (Figure 4) is expected and in accordance with previous observations (Hodson and Wilkins, 1991; Kopittke et al., 2015). However, the formation of Al-Si complexes within the mucigel or apoplast presumably occurred due to supersaturation resulting from the increased $\mathrm{Al}$ and $\mathrm{Si}$ concentrations within these root tissues (Figures 4, 5) together with an increased $\mathrm{pH}$. For example, it is has been reported that the $\mathrm{pH}$ of the root apoplast is generally 5-6 (Staal et al., 2011), compared to the bulk solution $\mathrm{pH}$ value of 4.5 in the present study. Indeed, it is known that the solubility 
of aluminosilicates and hydroxyaluminosilicates decrease as $\mathrm{pH}$ increases toward neutral (Lindsay, 1979; Exley and Birchall, 1992), and it is well-known that hydroxyaluminosilicates form in neutral and slightly alkaline solutions.

\section{CONCLUSION}

In accordance with previous studies, we have found that $\mathrm{Si}$ can potentially increase RER in Al-toxic solutions, with the magnitude of the effect increasing with the concentration of Si. This improvement in RER could not be attributed to a change in Al-chemistry of the bulk nutrient solution, with inorganic monomeric Al concentrations remaining constant despite the addition of $\mathrm{Si}$ at concentrations of up to $2 \mathrm{mM}$. Similarly, the improvement in RER could not be attributed to a decrease in the concentration of $\mathrm{Al}$ within the apical root tissues. We used LEXRF to examine the distribution of $\mathrm{Al}$ and $\mathrm{Si}$ within the rhizodermis and outer cortex in tissues $5 \mathrm{~mm}$ from the root apex. It was found that $\mathrm{Al}$ accumulated in the cell wall and mucigel, but that in roots also exposed to $\mathrm{Si}$, high concentrations of $\mathrm{Al}$ were observed to be co-located with $\mathrm{Si}$ in the mucigel and outer apoplast at the root-solution interface. Thus, the present study has shown that $\mathrm{Si}$ can reduce the toxicity of $\mathrm{Al}$ in planta through formation of $\mathrm{Al}-\mathrm{Si}$ complexes, with this presumably decreasing the strong binding of $\mathrm{Al}$ to the cell wall where it exerts its toxic effects. Given that $\mathrm{Si}$ is the second most abundant element in the earth's crust, the findings of the present study have important

\section{REFERENCES}

Barcelo, J., Guevara, P., and Poschenrieder, C. (1993). Silicon amelioration of aluminium toxicity in teosinte (Zea mays L. ssp. mexicana). Plant Soil 154, 249-255. doi: 10.1007/BF00012530

Baylis, A. D., Gragopoulou, C., Davidson, K. J., and Birchall, J. D. (1994). Effects of silicon on the toxicity of aluminium to soybean. Commun. Soil Sci. Plant Anal. 25, 537-546. doi: 10.1080/001036294093 69061

Broadley, M., Brown, P., Cakmak, I., Ma, J. F., Rengel, Z., and Zhao, F. J. (2012). "Beneficial elements," in Marschner's Mineral Nutrition of Higher Plants, 3rd Edn, ed. P. Marschner (San Diego, CA: Academic Press), 249-269.

Browne, B. A., and Driscoll, C. T. (1992). Soluble aluminum silicates: stoichiometry, stability, and implications for environmental geochemistry. Science 256, 1667-1670. doi: 10.1126/science.256.5064.1667

Cocker, K. M., Evans, D. E., and Hodson, M. J. (1998a). The amelioration of aluminium toxicity by silicon in higher plants: solution chemistry or an in planta mechanism? Physiol. Plant. 104, 608-614. doi: 10.1034/j.1399-3054.1998. 1040413.x

Cocker, K. M., Evans, D. E., and Hodson, M. J. (1998b). The amelioration of aluminium toxicity by silicon in wheat (Triticum aestivum L.): malate exudation as evidence for an in planta mechanism. Planta 204, 318-323. doi: 10.1007/ s004250050262

Corrales, I., Poschenrieder, C., and Barceló, J. (1997). Influence of silicon pretreatment on aluminium toxicity in maize roots. Plant Soil 190, 203-209. doi: 10.1023/A:1004209828791

Daikuhara, G. (1914). Ueber saure mineral boden. Bull. Imp. Cent. Agric. Exp. Stations Japan Tokyo Japan 2, 18.

Eswaran, H., Reich, P., and Beinroth, F. (1997). "Global distribution of soils with acidity," in Plant-Soil Interactions at Low pH, ed. A. C. Moniz (Sao Paulo: Brazilian Soil Science Society), 159-164. implications for understanding the toxic effects of the elevated levels of $\mathrm{Al}$ that occur in the estimated $30-40 \%$ of all arable soils worldwide are acid.

\section{AUTHOR CONTRIBUTIONS}

PK conceived the research program. PK, KG, and BM conducted the plant growth experiments. PK, AG, GK, and BM conducted LEXRF analyses at Elettra (Italy). PK wrote the first draft of the article to which all other authors contributed.

\section{FUNDING}

This work was supported by the Australian Research Council (ARC) through the Future Fellowship Scheme (FT120100277). Travel funding was provided by the International Synchrotron Access Program (ISAP) (AS/IA161/10724) managed by the Australian Synchrotron and funded by the Australian Government. Part of the research described here was conducted at the TwinMic beamline $(\mathrm{BL} 1.1 \mathrm{~L})$ of the Elettra Sincrotrone (Trieste, Italy).

\section{ACKNOWLEDGMENT}

The assistance of Professor Chris Exley (Keele University, United Kingdom) is appreciated.

Eticha, D., Stass, A., and Horst, W. J. (2005). Localization of aluminium in the maize root apex: can morin detect cell wall-bound aluminium? J. Exp. Bot. 56, 1351-1357. doi: 10.1093/jxb/eri136

Exley, C., and Birchall, J. D. (1992). Hydroxyaluminosilicate formation in solutions of low total aluminum concentration. Polyhedron 11, 1901-1907. doi: 10.1016/ S0277-5387(00)83738-9

Galvez, L., Clark, R. B., Gourley, L. M., and Maranville, J. W. (1987). Silicon interactions with manganese and aluminum toxicity in sorghum. J. Plant Nutr. 10, 1139-1147. doi: 10.1080/01904168709363642

Gianoncelli, A., Kaulich, B., Alberti, R., Klatka, T., Longoni, A., de Marco, A., et al. (2009). Simultaneous soft X-ray transmission and emission microscopy. Nucl. Instrum. Methods Phys. Res. A 608, 195-198. doi: 10.1016/j.nima.2009.06.035

Gianoncelli, A., Kourousias, G., Merolle, L., Altissimo, M., and Bianco, A. (2016). Current status of the TwinMic beamline at Elettra: a soft X-ray transmission and emission microscopy station. J. Synchrotron. Radiat. 23, 1526-1537. doi: 10.1107/S1600577516014405

Goldbach, H. E., Yu, Q., Wingender, R., Schulz, M., Wimmer, M., Findeklee, P., et al. (2001). Rapid response reactions of roots to boron deprivation. J. Plant Nutr. Soil 164, 173-181. doi: 10.1002/1522-2624(200104)164:2<173::AIDJPLN173>3.0.CO;2-F

Haynes, R. J. (1980). Ion exchange properties of roots and ionic interactions within the root apoplasm: their role in ion accumulation by plants. Bot. Rev. 46, 75-99. doi: $10.1007 / \mathrm{BF} 02860867$

Haynes, R. J. (2017). "Significance and role of Si in crop production," in Advances in Agronomy, ed. D. L. Sparks (San Diego, CA: Elsevier Academic Press Inc.), 83-166.

Hodson, M. J., and Evans, D. E. (1995). Aluminium/silicon interactions in higher plants. J. Exp. Bot. 46, 161-171. doi: 10.1093/jxb/46.2.161

Hodson, M. J., and Sangster, A. G. (1993). The interaction between silicon and aluminium in Sorghum bicolor (L.) Moench: growth analysis and X-ray microanalysis. Ann. Bot. 72, 389-400. doi: 10.1006/anbo.1993.1124 
Hodson, M. J., and Wilkins, D. A. (1991). Localization of aluminium in the roots of Norway spruce [Picea abies (L.) Karst.] inoculated with Paxillus involutus Fr. New Phytol. 118, 273-278. doi: 10.1111/j.1469-8137.1991. tb00977.x

Horst, W. J., Wang, Y., and Eticha, D. (2010). The role of the root apoplast in aluminium-induced inhibition of root elongation and in aluminium resistance of plants: a review. Ann. Bot. 106, 185-197. doi: 10.1093/aob/mcq053

Jones, D. L., Blancaflor, E. B., Kochian, L. V., and Gilroy, S. (2006). Spatial coordination of aluminium uptake, production of reactive oxygen species, callose production and wall rigidification in maize roots. Plant Cell Environ. 29, 1309-1318. doi: 10.1111/j.1365-3040.2006.01509.x

Kerven, G. L., Edwards, D. G., Asher, C. J., Hallman, P. S., and Kokot, S. (1989). Aluminum determination in soil solution: II. short-term colorimetric procedures for the measurement of inorganic monomeric aluminum in the presence of organic acid ligands. Aust. J. Soil Res. 27, 91-102. doi: 10.1071/ SR9890091

Kidd, P. S., Llugany, M., Poschenrieder, C., Gunsé, B., and Barceló, J. (2001). The role of root exudates in aluminium resistance and silicon-induced amelioration of aluminium toxicity in three varieties of maize (Zea mays L.). J. Exp. Bot. 52, 1339-1352. doi: 10.1093/jexbot/52.359.1339

Kinraide, T. B., Arnold, R. C., and Baligar, V. C. (1985). A rapid assay for aluminium phototoxicity at submicromolar concentrations. Physiol. Plant. 65, 245-250. doi: 10.1111/j.1399-3054.1985.tb02390.x

Kopittke, P. M., and Blamey, F. P. C. (2016). Theoretical and experimental assessment of nutrient solution composition in short-term studies of aluminium rhizotoxicity. Plant Soil 406, 311-326. doi: 10.1007/s11104-0162890-5

Kopittke, P. M., Moore, K. L., Lombi, E., Gianoncelli, A., Ferguson, B. J., Blamey, F. P. C., et al. (2015). Identification of the primary lesion of toxic aluminum (Al) in plant roots. Plant Physiol. 167, 1402-1411. doi: 10.1104/pp.114.253229

Lazof, D. B., Goldsmith, J. G., Rufty, T. W., and Linton, R. W. (1996). The early entry of $\mathrm{Al}$ into cells of intact soybean roots (a comparison of three developmental root regions using secondary ion mass spectrometry imaging). Plant Physiol. 112, 1289-1300. doi: 10.1104/pp.112.3.1289

Li, Y. C., Alva, A. K., and Sumner, M. E. (1989). Response of cotton cultivars to aluminum in solutions with varying silicon concentrations. J. Plant Nutr. 12, 881-892. doi: 10.1080/01904168909364000

Li, Y. C., Sumner, M. E., Miller, W. P., and Alva, A. K. (1996). Mechanism of silicon induced alleviation of aluminum phytotoxicity. J. Plant Nutr. 19, 1075-1087. doi: 10.1080/01904169609365181

Liang, Y., Nikolic, M., Bélanger, R., Gong, H., and Song, A. (2015). Silicon in Agriculture. Dordrecht: Springer.

Liang, Y., Yang, C., and Shi, H. (2001). Effects of silicon on growth and mineral composition of barley grown under toxic levels of aluminum. J. Plant Nutr. 24, 229-243. doi: 10.1081/PLN-100001384

Lindsay, W. L. (1979). Chemical Equilibria in Soils. New York, NY: John Wiley \& Sons.

Marienfeld, S., Schmohl, N., Klein, M., Schroder, W. H., Kuhn, A. J., and Horst, W. J. (2000). Localisation of aluminium in root tips of Zea mays and Vicia faba. J . Plant Physiol. 156, 666-671. doi: 10.1016/S0176-1617(00)80229-1

Menzies, N. W., and Bell, L. C. (1988). Evaluation of the influence of sample preparation and extraction technique on soil solution composition. Aust. J. Soil Res. 26, 451-464. doi: 10.1071/SR9880451

Nordstrom, D. K., and May, H. M. (1996). "Aqueous equilibrium data for mononuclear aluminum species," in The Environmental Chemistry of
Aluminum, 2nd Edn, ed. G. Sposito (Boca Raton, FL: CRC/Lewis Publishers), 39-80.

Oades, J. M. (1978). Mucilages at the root surface. J. Soil Sci. 29, 1-16. doi: 10.1111/ j.1365-2389.1978.tb02025.x

Parkhurst, D. (2014). PhreeqcI v3.1.7. Available at: http://water.usgs.gov/software/ [accessed December, 2014].

Pokrovski, G. S., Schott, J., Harrichoury, J. C., and Sergeyev, A. S. (1996). The stability of aluminum silicate complexes in acidic solutions from 25 to $150^{\circ} \mathrm{C}$. Geochim. Cosmochim. Acta 60, 2495-2501. doi: 10.1016/0016-7037(96)00123-8

Prabagar, S., Hodson, M. J., and Evans, D. E. (2011). Silicon amelioration of aluminium toxicity and cell death in suspension cultures of Norway spruce (Picea abies (L.) Karst.). Environ. Exp. Bot. 70, 266-276. doi: 10.1016/j. envexpbot.2010.10.001

Rogalla, H., and Romheld, V. (2002). Role of leaf apoplast in silicon-mediated manganese tolerance of Cucumis sativus L. Plant Cell Environ. 25, 549-555. doi: 10.1046/j.1365-3040.2002.00835.x

Saito, K., Yamamoto, A., Sa, T., and Saigusa, M. (2005). Rapid, micro-methods to estimate plant silicon content by dilute hydrofluoric acid extraction and spectrometric molybdenum method. Soil Sci. Plant Nutr. 51, 29-36. doi: 10.1111/j.1747-0765.2005.tb00003.x

Sangster, A. G., and Parry, D. W. (1976). Endodermal silicon deposits and their linear distribution in developing roots of Sorghum bicolor (L.) Moench. Ann. Bot. 40, 361-371. doi: 10.1093/oxfordjournals.aob.a085139

Sole, V. A., Papillon, E., Cotte, M., Walter, P., and Susini, J. (2007). A multiplatform code for the analysis of energy-dispersive X-ray fluorescence spectra. Spectrochim. Acta Part B At. Spectrosc. 62, 63-68. doi: 10.1016/j.sab.2006.12.002

Staal, M., De Cnodder, T., Simon, D., Vandenbussche, F., Van Der Straeten, D., Verbelen, J.-P., et al. (2011). Apoplastic alkalinization is instrumental for the inhibition of cell elongation in the Arabidopsis root by the ethylene precursor 1-aminocyclopropane-1-carboxylic acid. Plant Physiol. 155, 2049-2055. doi: $10.1104 /$ pp.110.168476

Taylor, G. J., Stadt, K. J., and Dale, M. R. T. (1991). Modeling the phytotoxicity of aluminum, cadmium, copper, manganese, nickel, and zinc using the Weibull frequency-distribution. Can. J. Bot. 69, 359-367. doi: 10.1139/b91-049

Veitch, F. P. (1904). Comparison of methods for the estimation of soil acidity. J. Am. Chem. Soc. 26, 637-662. doi: 10.1021/ja01996a005

von Uexküll, H. R., and Mutert, E. (1995). Global extent, development and economic impact of acid soils. Plant Soil 171, 1-15. doi: 10.1007/BF00009558

Wang, Y., Stass, A., and Horst, W. J. (2004). Apoplastic binding of aluminum is involved in silicon-induced amelioration of aluminum toxicity in maize. Plant Physiol. 136, 3762-3770. doi: 10.1104/pp.104.045005

Wolt, J. D. (1994). Soil Solution Chemistry: Applications to Environmental Science and Agriculture. New York, NY: Wiley.

Conflict of Interest Statement: The authors declare that the research was conducted in the absence of any commercial or financial relationships that could be construed as a potential conflict of interest.

Copyright (c) 2017 Kopittke, Gianoncelli, Kourousias, Green and McKenna. This is an open-access article distributed under the terms of the Creative Commons Attribution License (CC BY). The use, distribution or reproduction in other forums is permitted, provided the original author(s) or licensor are credited and that the original publication in this journal is cited, in accordance with accepted academic practice. No use, distribution or reproduction is permitted which does not comply with these terms. 